\title{
Toward a community impact assessment for food policy councils: Identifying potential impact domains
}

\author{
Larissa Calancie ${ }^{*}$ * \\ University of North Carolina at Chapel Hill \\ Holly Calhoun e \\ Public Health Institute \\ Kristen Cooksey-Stowers ${ }^{b}$ \\ Abbey Pinerf \\ University of Connecticut \\ North Carolina State University \\ Anne Palmerc \\ Karen Webb 9 \\ Johns Hopkins Center for a Livable Future \\ University of California, Berkeley \\ Natasha Frost d
Public Health Law Center
}

Submitted September 15, 2017 / Revised January 12 and February 9, 2018 / Accepted February 13, 2018 /

Published online September 24, 2018

Citation: Calancie, L., Cooksey-Stowers, K., Palmer, A., Frost, N., Calhoun, H., Piner, A., \& Webb, K. (2018). Toward

a community impact assessment for food policy councils: Identifying potential impact domains. Journal of A griculture,

Food Systems, and Community D evelopment, 8(3), 123-136. https:/ / doi.org/ 10.5304/ jafscd.2018.083.001

Copyright ( 2018 by the Authors. Published by the Lyson Center for Civic Agriculture and Food Systems. Open access under CC BY license.

\begin{abstract}
Food policy councils (FPCs) are collaboratives that work to strengthen food systems. Over 300 FPCs exist in the United States, Canada, and Tribal Nations. In 2015, we surveyed the types of initia-

a * Corresponding author: Larissa Calancie, Ph.D ., Center for Health Equity Research, D epartment of Social Medicine, School of Medicine, University of North Carolina at Chapel Hill; Chapel Hill, NC 27599 USA; +1-315-350-1689; lcalancie@unc.edu

${ }^{\mathrm{b}}$ Kristen Cooksey-Stowers, Ph.D ., Rudd Center for Food Policy and Obesity, University of Connecticut; 1 Constitution Plaza, Suite 600; Hartford, CT 06103 USA; kristen.cooksey@uconn.edu

c Anne Palmer, MAIA, Johns Hopkins Center for a Livable Future, Bloomberg School of Public Health; 615 North Wolfe Street W7010; Baltimore, MD 21205 USA; apalmer6@jhu.edu

d Natasha Frost, J.D ., Public Health Law Center; 875 Summit Avenue; St. Paul, MN 55105 USA; natasha.frost@mitchellhamline.edu

e Holly Calhoun, Public Health Institute; 555 12th Street, 10th Floor; O akland, CA 94607 USA; hcalhoun@ phi.org
\end{abstract}

tives FPCs undertook and identified food sector targets and domains of potential impact in an effort to inform comprehensive FPC impact assessments. FPCs ( $(\mathrm{N}=66)$ reported 317 policy, systems, and environmental initiatives. At least half

${ }_{\mathrm{f}}$ Abbey Piner, MHS, D epartment of Horticultural Science; Campus Box 7609; North Carolina State University; Raleigh, NC 27695 USA; abbey_piner@ ncsu.edu

g Karen Webb, Ph.D ., Nutrition Policy Institute, University of California, Berkeley; 2115 Milvia; Berkeley, California 94702 USA; lkwebb@ucanr.edu

\section{Funding Disclosure}

Research reported in this publication was supported by the Nutrition and Obesity Policy Research and Evaluation Network funded by the Prevention Research Centers at the Centers for D isease Control and Prevention (CDC) under A ward Number 3U48D P004998. The project described was also supported by the National Center for Advancing Translational Sciences, National Institutes of Health (NIH), through grant award no. UL1TR001111. The content is solely the responsibility of the authors and does not necessarily represent the official views of the NIH or the CDC. 
of these were focused on food production, and many were focused on institutional food service and the food assistance sectors. Commercial food service, food processing, and food waste were less often the focus. Potential impacts of their initiatives were classified into six domains: supporting resilient food systems (235, 74\%); increasing access to healthy foods $(171,54 \%)$; supporting economic development (115, 36\%); promoting equity in the food system (94, 30\%); promoting environmental sustainability (82, 26\%); and increasing knowledge of or demand for healthy foods (27, 9\%). Many initiatives were likely to impact multiple domains.

\section{Keywords}

Food Policy Council, Food System, Food Policy, Equity, Nutrition, Sustainability, Economic D evelopment, Local Agriculture, Natural Resources, Collaboration

\section{Introduction and Literature Review}

Food policy councils (FPCs) are collaboratives that bring together representatives from across the food system in order to identify food system issues, coordinate programs, and inform policy (Harper, Shattuck, Holt-Giménez, Alkon, \& Lambrick, 2009). Food systems are complex, adaptive systems that are composed of the individuals, organizations, inputs, and outputs (and the interactions between them) that are required to produce, process, distribute, sell, purchase, consume, and dispose of food (Nesheim, Oria, \& Tsai Y ih, 2015). Food systems vary in scale. They can be examined at many levels, from communities to global food systems (G odfray et al., 2010). In the United States and Canada, food systems' structures can give rise to complex problems, including hunger, obesity, degradation of natural resources, and equity concerns (Neff, Palmer, McKenzie, \& Lawrence, 2009). FPCs serve as an arena where members can develop a holistic view of a food system and take action to address food-related problems in their communities (Schiff, 2008). For example, in 2011 the Centers for Disease Control and Prevention (CDC) recommended FPCs as a strategy to increase fruit and vegetable consumption because councils aim to increase individuals' access to produce through policy and programs (CD C,
2011). Moreover, by soliciting community input and empowering members to champion food system issues, FPCs allow groups to practice "food democracy," defined as "the idea that people can and should be actively participating in shaping the food system, rather than remaining passive spectators on the sidelines. In other words, food democracy is about citizens having the power to determine agro-food policies and practices locally, regionally, nationally, and globally" (Hassanein, 2003, p.79). Cross-sector collaborations, such as FPCs, have the potential to influence environments such that healthy foods are broadly available, affordable, and produced using methods that protect natural resources (Schiff, 2008).

There are over 300 FPCs in the U.S. and Canada (Food Policy Network, 2015), yet research on the impact FPCs have on policy, systems, and environmental-level change (PSE) is limited. The CD C recognizes that individuals' environments influence their health behaviors, and thus recommend strategies that promote PSE change as a promising approach to reduce obesity and promote public health (Honeycutt et al., 2015; Lyn et al., 2013). Existing FPC literature describes council and network structures (Freedman \& Bess, 2011; Harper et al., 2009), activities and food system priorities (Scherb, Palmer, Frattaroli, \& Pollack, 2012), and developing partnerships as a mechanism to facilitate food system change (Clayton, Frattaroli, Palmer, \& Pollack, 2015). Several case studies describe how individual FPCs influence policies and suggest impacts those policies could have on their communities (McCartan \& Palermo, 2017; Walsh, Taggart, Freedman, Trapl, \& Borawski, 2015). However, there are no studies that systematically evaluate the impact that a large sample of FPCs are likely to have on policies, systems, and environments within their communities. Capwell and colleagues identified the following six reasons why evaluation is useful for community public health initiatives: "i) to determine achievement of objectives related to improved health status; ii) to improve program implementation; iii) to provide accountability to funders, community, and others; iv) to increase community support for initiatives; v) to contribute to the scientific base for community public health interventions; and vi) to inform 
policy decisions" (Capwell, Butterfoss, \& Francisco, 2000, p. 15). Additionally, council initiatives may produce unintended negative consequences that may go undetected if they are not captured in impact evaluations (Chavis, 2001).

While evaluating the impacts FPCs have on PSEs in their communities is critical, doing so is challenging. Community collaboratives impact communities directly through programs and policies and indirectly through the efforts of their members, their organizations, and other stakeholders (Javdani \& Allen, 2011; Roussos \& Fawcett, 2000). O ne FPC coordinator explained, "Because much of our work is indirect, facilitative, and collaborative, it's difficult to isolate the impacts of our specific efforts" (MacRae \& D onahue, 2013, p.17). Moreover, FPCs are working to influence food systems, which are complex. Ascertaining cause and effect is complicated by time delays and feedback loops, which are hallmarks of complex systems (Vennix, 1996). Identifying the broad domains and sectors that FPCs influence can help organize the challenging task of evaluating change in the complex food system (Anderson Steeves, Martins, \& Gittelsohn, 2014).

In this study, we suggest a classification system for categorizing the potential impacts FPCs may have in their communities as an initial step toward a comprehensive, systematic FPC impact assessment. The categories we identified are domains of potential impact. Identifying domains, or constructs, is an early step in item and scale development (D eV ellis, 2012). Constructs are ideas that are not directly observable; thus, they are measured using items that are thought to reflect that construct (D eV ellis, 2012). Scales are a method of data collection for evaluation and research. We employed directed content analysis, a qualitative method where researchers use existing theories or frameworks to develop initial codes, and then iteratively analyze text (Hsieh \& Shannon, 2005). In this case, we analyzed the text of 317 PSE initiatives reported by FPCs to develop a coding scheme for potential impact domains. We then iteratively coded the text and reported the frequency and types of initiatives in each domain. The potential impact domains could inform FPC community impact assessments.

\section{Applied Research Methods}

D ata Collection

In 2015, members of 278 FPCs throughout the United States, Canada, and Tribal Nations were invited to complete a survey using the Food Policy Council Self-Assessment Tool (FPC-SAT) (Calancie et al., 2017). The assessment tool was adapted from a study of intimate partner violence prevention councils (Allen, Javdani, Lehrner, \& Walden, 2012). The Institutional Review Board at the University of North Carolina at Chapel Hill exempted this study. Experts in survey development, FPCs, nutrition, public health, and law reviewed the assessment tool. Cognitive response interviews were conducted with a convenience sample of four FPC leaders or members to elicit feedback on the questions and to verify that potential participants would accurately interpret FPC-SAT questions. The experts and interviewees suggested shortening the assessment tool, using consistent question stems within question blocks, and rephrasing several questions. Those changes were made and then the assessment tool was pilottested with members from $17 \mathrm{FPCs}$ before it was used to collect data from a large sample of FPCs. All active FPCs whose contact information listed in the Food Policy Network's Food Policy Council Directory in 2015 (Food Policy Network, 2015) were asked to participate in this study via a recruitment email. The email contained a study description and an electronic link to the FPC-SAT. Contact persons at FPCs were asked to complete the survey and to share the survey link with their council members. Each participant was eligible for a US\$5 gift card as an incentive, and councils where eight or more members completed the assessment tool received a feedback report summarizing their members' perception of the council. Members' perceptions were aggregated and presented anonymously in the feedback reports. Three reminders were sent to FPC contact persons, asking them to complete the assessment tool and to remind their members to complete the tool.

The FPC-SAT included an item asking participants to report PSE initiative with which their council was involved (Q uestion text: "Please list and describe changes in: policy e.g., bee keeping 
ordinance, zoning for community gardens; systems e.g., connected food-related organizations; environments e.g., influenced menus in hospital cafeterias; and/ or organizational practices e.g., use of local foods in schools; that your council helped facilitate over the last 12 months"). Participants recorded their responses in an open text field. Since FPC members each completed an FPC-SAT, members within the same FPC frequently reported the same PSE initiatives. In those cases, each PSE was only counted once per council.

$D$ ata $A$ nalysis

Members of the CDC Nutrition and O besity Policy Research and Evaluation Network (NOPREN) FPC Working Group (Blanck \& Kim, 2012) conducted a directed content analysis of the openended assessment item described above. The Working G roup includes researchers and practitioners with expertise in law, public policy, public health, food systems, cross-sector collaboration, nutrition, community interventions, food policy, equity, and FPCs. The Working G roup reviewed all of the initiatives reported by FPCs and developed coding procedures for food system sectors and potential impacts of reported PSE initiatives. All study authors worked in pairs to categorize the reported initiatives into potential impact domains or food system sectors. More than one potential impact domain was applied if there was sufficient information provided to do so. Those with insufficient information to infer potential impacts were coded as such. Pairs of coders reviewed their initiative codes and discrepancies were resolved through discussion until a consensus was reached. One researcher reviewed all coded initiatives for quality and consistency.

Initiatives by food system sectors and topics We used a variety of food system descriptions and frameworks, particularly those described by Sobal, Kettel K han, and Bisogni (1998) and Heywood and Lund-Adams (1991), to guide the development of relevant and practical classifications of FPC initiatives into sectors of the food system, as follows:

(1) local agriculture and/ or food production,

(2) food processing, (3) food retailing, (4) institutional food service, (5) commercial food service,
(6) food assistance and charitable foods, (7) food waste, and (8) other initiatives. Reported initiatives that were not specific to a particular sector or for which insufficient information was provided were classified as "other." Initiatives could be classified into more than one sector. FPC reported initiatives were also grouped into topics, which were developed inductively.

Initiatives by potential impact domains

The coding scheme for potential impacts of reported initiatives was informed by the Healthy Food Policy Project framework that is under development by the Public Health Law Center, the University of Connecticut's Rudd Center for Food Policy and Obesity, and the Vermont Law School's Center for Agriculture and Food Systems. The following six domains of potential impact were identified by the NOPREN working group.

(1) Increase access to healthy food (such as fruits, vegetables, and whole grains) refers to initiatives that aim to increase availability (supply of food), affordability (cost), food safety, and cultural appropriateness of food (Caspi, Sorensen, Subramanian, \& Kawachi, 2012). Healthy foods contribute to eating patterns that emphasize fruits, vegetables, beans, legumes, whole grains, dairy, seafood and plant-based protein, minimally processed meats and poultry, eggs, nuts, seeds, and non-hydrogenated oils. Healthy foods also contribute to eating patterns that limit the consumption of refined grains, sugar, trans fats, and sodium (G uenther et al., 2013; Salas-Salvado et al., 2011; U.S. D epartment of Health and Human Services and U.S. D epartment of Agriculture, 2015). These eating patterns are associated with a decreased risk for developing diet-related chronic disease (Mozaffarian, 2016). Actions that lowered the price of healthy foods or beverages were included in this category.

(2) Increase knowledge of and/ or demand for healthy foods refers to initiatives that increase community members' motivation and capacity to consume healthy foods by providing information, marketing, and other consumer-directed strategies. Actions that influenced knowledge or demand for products, 
such as marketing campaigns, were categorized here.

(3) Promote equity in the food system refers to initiatives that reduce disadvantage and disparities in outcomes (such as food security, nutrition, employment opportunities, and health), regardless of one's race or ethnicity, religion, socioeconomic status, gender, age, or mental health; cognitive, sensory, or physical disability; sexual orientation or gender identity; and/ or geographic location (Office of Disease Prevention and Health Promotion, 2008; Ransom, G reiner, \& Kochtitzky, 2011).

(4) Support economic development refers to initiatives that increase or promote opportunities to generate income for individuals and communities.

(5) Promote environmental sustainability refers to approaches that increase the likelihood that natural resources such as clean water, clean air, biodiversity, and productive soil will exist for future generations (Thompson \& Ikerd, 2009). Examples of

Table 1. Food Policy Councils (FPCs); Regional Distribution of Respondents to 2015 Survey ( $\mathrm{N}=66$ ) Compared with Those Listed in the 2016 Food Policy Council Directory

\begin{tabular}{lcc}
\hline Country and Region & $\begin{array}{c}\text { FPCs reporting initiatives } \\
\text { in this study; } \\
\mathrm{n}(\%)\end{array}$ & $\begin{array}{c}\text { FPCs listed in the 2016 } \\
\text { Food Policy Network } \\
\text { Directory; } \\
\mathrm{n}(\%)\end{array}$ \\
\hline United States & $68(22 \%)$ \\
\hline West & $18(27 \%)$ & $69(24 \%)$ \\
\hline Midwest & $11(17 \%)$ & $65(21 \%)$ \\
\hline South & $15(23 \%)$ & $40(13 \%)$ \\
\hline Northeast & $10(15 \%)$ & $4(1 \%)$ \\
\hline Tribal Nations (US) & $2(3 \%)$ & $21(7 \%)$ \\
\hline Canada & $1(2 \%)$ & $7(2 \%)$ \\
\hline West & 0 & $39(12 \%)$ \\
\hline Prairies & $7(11 \%)$ & $3(1 \%)$ \\
\hline Central & 0 & 0 \\
\hline Atlantic & $2(3 \%)$ & 316 \\
\hline Unknown & 66 &
\end{tabular}

a Source: Sussman \& Bassarab, 2017. sustainable food production methods include aquaponics, organic farming, and non-toxic pesticide use.

(6) Support a resilient food system includes initiatives that allow food systems and their component sectors to withstand shocks and disturbances, both human-caused and natural, over time (Toth, Rendall, \& Reitsma, 2016). Resilience also includes the ability of food system actors to respond to disruptions by activating social networks to which they belong (Toth et al., 2016). Initiatives that connect groups and sectors to support and build infrastructure for the local food system are regarded as having the potential to promote resilience because they may shorten distribution networks and supply chains and provide food to nearby populations, should national or international food distribution networks be disrupted (Toth et al., 2016).

\section{Results}

Members of 66 FPCs ( $24 \%$ of those contacted)

from the U.S., Canada, and Tribal Nations responded to the survey. This is comparable to the geographic distribution of FPCs listed in the most recent FPC D irectory (Table 1) (Sussman \& Bassarab, 2017). In our sample, $27 \%$ of councils were from the Western U.S., $17 \%$ from the Midwest, $23 \%$ from the South, and $15 \%$ from the Northeast. In the 2016 FPC Directory, 22\% were from the Western U.S., 24\% from the Midwest, $21 \%$ from the South, and 13\% from the Northeast. Three percent of our sample was from Tribal Nations; $1 \%$ of those listed in the 2016 FPC Directory were from Tribal Nations. Two percent of our sample was from the Canadian West, none from the Prairies, 11\% from Central Canada, and 3\% from the Canadian Atlantic provinces. In the $2016 \mathrm{D}$ irectory, $7 \%$ were from the Canadian West, $2 \%$ from the Prairies, $12 \%$ from Central Canada, and 1\% from the Canadian 
Atlantic provinces. The average FPC had been in place for 6.7 years (range 1-33 years). The most frequently reported FPC age was three years. The average council age listed in the 2016 D irectory is six years (range 1-34 years), and the most frequently reported age was four years.
FPC Initiatives by F ood System Sectors

FPCs reported a total of 317 PSE initiatives over the 12 months prior to the survey. Table 2 shows the initiatives classified by the sectors of the food system they influence or target. Initiatives could apply to a single sector or a combination of sectors.

Table 2. Policy, Systems, and Environment Initiatives (PSE) by Topic and Sector of the Food System Reported by Members of 66 Food Policy Councils in 2015

\begin{tabular}{|c|c|}
\hline $\begin{array}{l}\text { PSE initiative topic by } \\
\text { food system sector a }\end{array}$ & $\begin{array}{l}\text { Example initiatives reported } \\
\text { by food policy council members }\end{array}$ \\
\hline \multicolumn{2}{|c|}{ LOCAL AGRICULTURE AND/ OR FOOD PRODUCTION SECTOR ( $n=159,50 \%)$} \\
\hline $\begin{array}{l}\text { Urban agriculture: } \\
\text { - Land use policies } \\
\text { - Zoning } \\
\text { - Permits and regulations } \\
\end{array}$ & $\begin{array}{l}\text { - Supported city regulations to preserve and protect local agricultural land } \\
\text { - Revised urban agriculture zoning code (bees, chickens, goats and farm stand } \\
\text { permits), and farm-gate sales }\end{array}$ \\
\hline $\begin{array}{l}\text { Enact "local food" procurement policies } \\
\text { in schools b }\end{array}$ & $\begin{array}{l}\text { - Worked with the largest urban school district to create local food procurement } \\
\text { guidelines }\end{array}$ \\
\hline $\begin{array}{l}\text { Enact "local food" procurement policies } \\
\text { in other settings }\end{array}$ & $\begin{array}{l}\text { - Advocated for "buy local" county policy } \\
\text { - Helped adopt workplace local food policy }\end{array}$ \\
\hline $\begin{array}{l}\text { Support farmers markets } \\
\text { (including acceptance of food } \\
\text { assistance benefits for purchases) }\end{array}$ & $\begin{array}{l}\text { - Removed state regulatory barrier for farmers markets } \\
\text { - Established farmers market and community fairs with multiple partners for } \\
\text { low-income, food desert areas } \\
\text { - Implemented a grant program to help farmers markets accept food stamps }\end{array}$ \\
\hline Support community gardens & $\begin{array}{l}\text { - Encouraged donation of private land into community gardens through the } \\
\text { limitation of legal liability }\end{array}$ \\
\hline \multicolumn{2}{|r|}{ FOOD PROCESSING SECTOR ( $n=16,5 \%)$} \\
\hline Support the cottage food industry & $\begin{array}{l}\text { - Supported city ordinance to permit the sale of home-grown fresh produce and } \\
\text { cottage foods from residences }\end{array}$ \\
\hline $\begin{array}{l}\text { Support local processing, preparation } \\
\text { and distribution facilities }\end{array}$ & $\begin{array}{l}\text { - Established a community kitchen } \\
\text { - Established a meat-processing plant and investigated the feasibility of a } \\
\text { poultry-processing facility } \\
\text { - Conducted a feasibility study for establishing a food hub }\end{array}$ \\
\hline \multicolumn{2}{|r|}{ FOOD RETAIL SECTOR ( $n=43,14 \%)$} \\
\hline $\begin{array}{l}\text { Conduct and/ or support promotions of } \\
\text { the sale and/ or use of "local foods" }\end{array}$ & $\begin{array}{l}\text { - Conducted a campaign with several grocery stores and dozens of local } \\
\text { farmers, including public outreach and creation of a wholesale local food } \\
\text { directory to connect buyers and farmers } \\
\text { - Promoted/pilot tested healthy food and fresh produce in retail store }\end{array}$ \\
\hline $\begin{array}{l}\text { Increase the number of healthy food } \\
\text { outlets }\end{array}$ & - Legalized mobile grocery stores (Mobile food stores ordinance) \\
\hline \multicolumn{2}{|c|}{ INSTITUTIONAL FOOD SERVICE SECTOR ( $\mathrm{n}=63,20 \%)$} \\
\hline Improve school food & - Installed 20 salad bars in the district's public schools \\
\hline Enact “local food” procurement policies & $\begin{array}{l}\text { - Passed a resolution to procure at least } 50 \% \text { local foods for use in the local } \\
\text { school system. } \\
\text { - Passed a policy for institutional purchasing from local farms }\end{array}$ \\
\hline $\begin{array}{l}\text { Support the development and/or imple- } \\
\text { mentation of school wellness policies }\end{array}$ & $\begin{array}{l}\text { - Convened school wellness seminars for local school districts to } \\
\text { implement/adopt wellness policies }\end{array}$ \\
\hline
\end{tabular}


Journal of Agriculture, Food Systems, and Community Development ISSN: 2152-0801 online

https:/ / www.foodsystemsjournal.org

Table 2, continued

COMMERCIAL FOOD SERVICE SECTOR ( $\mathrm{n}=13,4 \%)$

Advocate for zoning changes (excluding - Passed mobile vending policies and/ or ordinances near schools at the city urban agriculture zoning policies) and county level

FOOD ASSISTANCE \& CHARITABLE FOODS SECTOR $(n=45,14 \%)$

Increase access to free or low-cost foods - Helped start a farmers market in food-insecure neighborhood that takes EBT through programs and SNAP use marketwide and partners with WIC

- Included local produce in Meals on Wheels

- Promoted "please give nutritiously"

- Organized a gleaning program with local growers

Raise community awareness - Held event to raise community awareness of the need to end hunger FOOD WASTE SECTOR ( $n=3,<1 \%)$

Raise community awareness and remove - Held community event to raise awareness of the need to reduce food waste barriers to composting - Eased requirements to increase composting

OTHER INITIATIVES $(n=74,23 \%)$

Improve and support FPC functioning:

- Building connections, networking

- Changing FPC structure, governance

Facilitate food system assessments, food charters, or general food planning

Raise public education and awareness about food system issues

- Connected a remote rural region to other community food system organizations across the state through the new statewide food system network.

Promote communitywide nutrition or healthy living initiatives

- Sought endorsement of food charter by municipalities and committees

a Initiatives can target more than one sector.

b Schools are a unique setting because they are subject to federal nutrition standards.

The most common sector targeted by the initiatives was local agriculture and/ or food production (159, 50\%), followed by other initiatives (74, 23\%), institutional food service (63, 20\%), food assistance \& charitable foods (45, 14\%), food retail $(43,14 \%)$, food processing $(16,5 \%)$, commercial food service $(13,4 \%)$, and food waste $(3,<1 \%)$. Among the most common initiatives were those related to the preservation of a viable local food production system including advocacy for ordinances, policies and plans to preserve agricultural land in urban areas, creation of community gardens, and easing regulations to permit more backyard farming. Institutional food service initiatives frequently addressed school meal programs and procurement policies for hospitals and government buildings. Initiatives targeting the food retail sector included mobile grocery store policies and activities to increase the availability and appeal of local farms within retail settings such as grocery stores. Many food assistance and charitable food initiatives focused on increasing the supply of donated foods for distribution through community food drives and gleaning programs; others focused on raising awareness about hunger in the community. Food processing initiatives included instituting policies permitting the sale of certain home grown and homemade goods, establishing a community kitchen, and investigating the feasibility of food hubs and processing facilities. Commercial food service initiatives included mobile food vending policies and menu labeling in restaurants. Food waste policies and initiatives were uncommon $(<1 \%)$, but those few that reported initiatives in this sector focused on composting education, easing composting requirements, and raising community awareness of the need to reduce food waste.

Potential Impacts of FPC Initiatives Most frequently reported were initiatives with the 
potential to promote resilience in the food system (235, 74\%), increase access to healthy foods (171, $54 \%$ ), and support economic development (115, $36 \%$ ) (Table 3). Less often reported were those that aim to promote equity within the food system (94, 30\%), promote environmental sustainability (82, 26\%), and increase consumer knowledge of and/ or demand for healthy foods (27, 9\%). Many PSE initiative topics were considered to have multiple potential impacts (Table 4). For example, farmers markets that promoted products from farms that use sustainable farming practices were regarded as having the potential to promote environmental sustainability and increase access to healthy foods. Some initiatives, such as those addressing urban agriculture, promoting local food procurement in schools, and supporting farmers markets had potential impacts in most of the six impact categories. For example, of the 38 urban agriculture PSE initiatives that FPC members reported, nearly all had a potential impact on increasing access to healthy foods, promoting environmental sustainability, and supporting a resilient food system.

\section{Discussion}

FPCs have the opportunity to work in all sectors of the food system to influence policies, systems, and environments in their communities that affect health, economic prosperity, equity, environmental sustainability, and resilience of the local food system (Nesheim et al., 2015). In this study, FPCs reported PSE and other initiatives that were predominantly within the local agriculture and/ or food production sector, including initiatives for its preservation, promotion, growth, and use of sustainable practices. Many FPC initiatives also contributed to the food assistance and/ or charitable food sector and to institutional food services.

There were many potential benefits of initiatives reported by FPCs, including resilience of the local food system, improving access to healthful foods, and contributing to local economic development. Several initiatives supporting farmers markets had the potential to increase access to healthy foods (Ruelas, Iverson, Kiekel, \& Peters, 2012; Sadler, 2016), support economic development (Hughes, Brown, Miller, \& McConnell, 2008),

Table 3. Potential Impacts of Policy, Systems, and Environment Initiatives ( $N=317)$ Reported by Members of 66 Food Policy Councils in 2015

\begin{tabular}{lcl}
\hline PSE Initiative Category & $\begin{array}{c}\text { Number of reported } \\
\text { initiatives; } \mathrm{n}(\%)\end{array}$ & Examples \\
\hline $\begin{array}{l}\text { Support a resilient food } \\
\text { system }\end{array}$ & $235(74 \%)$ & $\begin{array}{l}\text { - Proposed farmland trust initiative } \\
\text { - Facilitated relationships between food-related organizations }\end{array}$ \\
\hline $\begin{array}{l}\text { Increase access to healthy } \\
\text { food }\end{array}$ & $171(54 \%)$ & $\begin{array}{l}\text { - Supported zoning for farm stands } \\
\text { - Facilitated EBT machine use at farmers markets }\end{array}$ \\
$\begin{array}{l}\text { Support economic } \\
\text { development }\end{array}$ & $\begin{array}{l}\text { - Passed cottage food industry laws } \\
\text { - Increased the number of healthy food outlets, farmers markets, and } \\
\text { food hubs, and promoting local food procurement at schools and } \\
\text { institutions (thus creating markets for local farmers) }\end{array}$ \\
$\begin{array}{l}\text { Promote equity in the food } \\
\text { system }\end{array}$ & $94(30 \%)$ & $\begin{array}{l}\text { - Passed staple food ordinance that requires all stores with a grocery } \\
\text { store license to sell a greater quantity of healthy foods, including } \\
\text { fruits and vegetables }\end{array}$ \\
\hline $\begin{array}{l}\text { - Improved public school food programs } \\
\text { Promote environmental }\end{array}$ & $82(26 \%)$ & $\begin{array}{l}\text { - Supported zoning for community gardens and urban agriculture (thus } \\
\text { increasing biodiversity in an area) }\end{array}$ \\
\hline $\begin{array}{l}\text { Increase knowledge of and/ } \\
\text { or demand for healthy foods }\end{array}$ & $27(9 \%)$ & $\begin{array}{l}\text { - Supported city pollinator resolution buy fresh buy local initiatives } \\
\text { - Facilitated farm-to-school and school nutrition collaboration among } \\
\text { agencies }\end{array}$ \\
\hline
\end{tabular}

a Farm-to-school has a nutrition education component. 
Table 4. Number of Policy, Systems, and Environmental (PSE) Initiatives in Each Topic Categorized by Potential Impact; $n=66$ Food Policy Councils; Heat Map a

\begin{tabular}{|c|c|c|c|c|c|c|c|}
\hline \multirow{2}{*}{\multicolumn{2}{|c|}{ Topic of PSE change }} & \multicolumn{6}{|c|}{ Potential impact category } \\
\hline & & $\begin{array}{l}\text { Increase access to } \\
\text { healthy food }\end{array}$ & $\begin{array}{l}\text { Increase knowledge } \\
\text { of and/ or demand } \\
\text { for healthy foods }\end{array}$ & $\begin{array}{l}\text { Promote equity in } \\
\text { the food system }\end{array}$ & $\begin{array}{l}\text { Support economic } \\
\text { development }\end{array}$ & $\begin{array}{l}\text { Promote } \\
\text { environmental } \\
\text { sustainability }\end{array}$ & $\begin{array}{l}\text { Support a resilient } \\
\text { food system }\end{array}$ \\
\hline 1 & School wellness programs & 3 & 0 & 0 & 0 & 0 & 0 \\
\hline 2 & Cottage food industry & 0 & 0 & 0 & 2 & 0 & 0 \\
\hline 3 & Local food campaign & 0 & 7 & 0 & 0 & 0 & 1 \\
\hline 4 & $\begin{array}{l}\text { Increasing the number of healthy } \\
\text { food outlets }\end{array}$ & 8 & 0 & 4 & 8 & 0 & 8 \\
\hline 5 & $\begin{array}{l}\text { Food hubs, processing facility, or } \\
\text { community kitchen }\end{array}$ & 0 & 2 & 2 & 10 & 0 & 7 \\
\hline 6 & $\begin{array}{l}\text { Food system assessments, food } \\
\text { charters, or general food planning }\end{array}$ & 2 & 0 & 5 & 1 & 1 & 20 \\
\hline 7 & Urban agriculture & 37 & 2 & 1 & 6 & 38 & 38 \\
\hline 8 & $\begin{array}{l}\text { Building connections between } \\
\text { organizations or supported another } \\
\text { organization, or activities related to } \\
\text { how the council functions (structure, } \\
\text { governance, etc.) }\end{array}$ & 10 & 1 & 8 & 9 & 2 & 44 \\
\hline 9 & $\begin{array}{l}\text { Increasing access to free or low-cost } \\
\text { foods through programs and SNAP } \\
\text { use }\end{array}$ & 14 & 0 & 14 & 5 & 7 & 9 \\
\hline 10 & Supporting community gardens & 21 & 0 & 0 & 2 & 21 & 21 \\
\hline 11 & $\begin{array}{l}\text { Promoting local food procurement in } \\
\text { schools }\end{array}$ & 21 & 12 & 21 & 21 & 0 & 21 \\
\hline 12 & Supporting farmers markets & 25 & 1 & 17 & 25 & 0 & 25 \\
\hline 13 & Influencing institutional purchasing & 7 & 0 & 1 & 14 & 0 & 15 \\
\hline 14 & Improving school food & 11 & 0 & 11 & 0 & 0 & 0 \\
\hline 15 & $\begin{array}{l}\text { Zoning (excluding urban agriculture } \\
\text { zoning policies) }\end{array}$ & 0 & 0 & 0 & 0 & 0 & 0 \\
\hline 16 & $\begin{array}{l}\text { Public education or awareness } \\
\text { raising about food system issues }\end{array}$ & 6 & 0 & 6 & 0 & 1 & 1 \\
\hline
\end{tabular}




\begin{tabular}{|c|c|c|c|c|c|c|c|}
\hline 17 & $\begin{array}{l}\text { Direct engagement with policy } \\
\text { makers or government departments }\end{array}$ & 4 & 0 & 3 & 5 & 3 & 8 \\
\hline 18 & $\begin{array}{l}\text { Influencing agriculture and general } \\
\text { land use }\end{array}$ & 0 & 0 & 1 & 7 & 7 & 15 \\
\hline 19 & $\begin{array}{l}\text { Promoting community-wide nutrition } \\
\text { or healthy living initiatives }\end{array}$ & 1 & 2 & 0 & 0 & 0 & 0 \\
\hline \multirow[t]{2}{*}{20} & Other & 1 & 0 & 0 & 0 & 2 & 2 \\
\hline & Total & 171 & 27 & 94 & 115 & 82 & 235 \\
\hline
\end{tabular}

a Shading occurs across rows such that the cells containing the highest number of initiatives within the row are the darkest, and the cells with the fewest initiatives within that row are the lightest.

and support a resilient food system by diversifying the types of food outlets in a community (Gillespie, Hilchey, Hinnichs, \& Feenstra, 2007). Additionally, several initiatives to assist farmers markets to locate in low resource areas and/ or acoept EBT benefits were classified as promoting equity (Buttenheim, Havassy, Fang, Glyn, \& Karpyn, 2012; Jones \& Bhatia, 2011).

Promoting equity within the food system was less often associated with reported initiatives; yet equity is an area where FPCs, as multisector collaboratives, oould become more influential (National Academies of Sciences, Engineering, and Medicine, 2017). FPCs can promote equity by several means including recruiting socioeconomically and demographically diverse groups to join their councils and participate in policy development; undertaking policy work that will maximize benefits for those groups that experience health and eoonomic disparities; and considering the social determinants of health in all their policy work in food systems (e.g., food system worker conditions, living wage) (Thomton et al., 2016).

Evaluation research on PSE interventions is relatively new, and evidenoe is limited for identifying which approaches are "best bets." The information and criteria that FPCs use for 'envisioning' and articulating their desired impacts, as well as selecting PSEs and sectors of the food system for their work are unclear and likely vary between councils. Systematic approaches to setting prionities could be useful for informing and enhancing FPC work. Similar to the approach used in this paper, FPCs could conduct an analysis of their initiatives (and those of community partners) by food system sectors and potential impacts to highlight strengths and gaps. In addition, greater economic constraints on public funding place more importance on selecting actions that are most effective, or show the most promise in achieving the desired impacts. Moreover, public health practitioners report limited access to digestible research evidence on what is most effective to do and how to do it most effectively. Timely and distilled information about promising interventions has been identified as key to its usefulness in decision making (Leeman et al., 2015). Future surveys could include questions about certain details of FPC initiatives and intended impacts, as well as the need for research evidence and training for setting prionities.

This study has limitations. Coding teams assigned potential impacts to reported FPC initiatives, but the outoomes and impacts of FPC initiatives were not evaluated, and indeed, outcome studies of FPCs are rare. Others have called for such studies as an important basis for informing future work (Harper et al., 2009; Scherb et al., 2012). While FPC survey respondents were representative of the regional distribution of all FPCs, the response rate of $24 \%$ may affect the representativeness of our findings. However, this study serves as an initial investigation to identify domains of potential impact FPCs can have in their communities. Additional research should be conducted with a larger sample of FPCs to detemine if the domains 
identified here capture the breadth of domains that FPCs work to influence. We may also have misclassified or undercounted the food system sectors or potential impacts of some initiatives due to insufficient detail provided. For example, many local food initiatives were reported that were not coded as 'promoting environmental sustainability' because there was no mention of production practices. Those initiatives may be intended to promote sustainability, but the research team did not have enough detail about them to code them as such. Future FPC impact assessments should gather enough detail about FPC initiatives to determine their impact across multiple domains. Finally, several FPC members described their councils' efforts to support the internal work of their FPC, including gaining official recognition, developing by-laws, expanding membership, and developing working groups. While these initiatives are certainly critical functions in building the capacity of FPCs, they were not the focus of this analysis and were, therefore, excluded.

\section{Conclusions and Recommendations for Research and Practice}

The purpose of this study was to develop and apply a classification system to broadly categorize the potential impacts that FPCs' policy, systems, and environmental initiatives have in their communities. This is an initial step toward developing a comprehensive impact assessment for FPCs. Such an assessment could be completed independently, or integrated into existing assessment tools, such as the FPC-SAT (Calancie et al., 2017). Moreover, the broad impact categories we identified in this study may help councils identify and communicate how their activities have the potential to impact factors that are important to representatives from diverse organizations, both internal and external to the council. For example, communicating that using local food in school meals programs can impact health equity, access to healthy foods, support the local economy, and promote resilient food systems could engender support from a variety of funders, community organizations, partners, and decisionmakers who might not otherwise appreciate the broad value of such an initiative. Multisector support for food system change can lead to sustainable funding streams, increased influence with policy and decision-makers, and engagement from a broad range of community organizations. Finally, the broad impact domains of the FPCs reflect the Institute of Medicine's characterization of the food system as a complex system that influences health, natural resources, the economy, and the social fabric of society (Nesheim et al., 2015). Strengthening food systems is, therefore, a strategy that may help address complex problems in the U.S., Canada, and Tribal Nations.

\section{Acknowledgments}

This work was conducted at the Center for Health Promotion and Disease Prevention at the University of North Carolina at Chapel Hill, a Prevention Research Center (5U48D P001944) and the Center for Health Equity Research. We would like to acknowledge the Kansas Health Foundation, the Food Policy Network, and the food policy council participants.

\section{References}

Allen, N. E., Javdani, S., Lehrner, A. L., \& Walden, A. L. (2012). "Changing the text": Modeling council capacity to produce institutionalized change. A merican Journal of Community Psychology, 49(3-4), 317-331. https:// doi.org/ 10.1007/ s10464-011-9460-z

Anderson Steeves, E., Martins, P. A., \& Gittelsohn, J. (2014). Changing the food environment for obesity prevention: Key gaps and future directions. C urrent 0 besity Reports, 3(4), 451-458. https:/ / doi.org/ 10.1007/ s13679-014-0120-0

Blanck, H. M., \& Kim, S. A. (2012). Creating supportive nutrition environments for population health impact and health equity: An overview of the Nutrition and O besity Policy Research and Evaluation Network's efforts. A merican Journal of Preventive M edicine, 43(3), S85-S90. https:/ / doi.org/ 10.1016/ j.amepre.2012.06.005

Buttenheim, A., Havassy, J., Fang, M., G lyn, J, \& Karpyn, A. E. (2012). Increasing supplemental nutrition assistance program/ electronic benefits transfer sales at farmers' markets with vendor-operated wireless point-of-sale terminals. Journal of the A cademy of N utrition and D ietetics, 112(5), 636-641. https:// doi.org/ 10.1016/ j.jand.2011.12.021 
Calancie, L., Allen, N. E., Weiner, B. J., Ng, S. W., Ward, D. S., \& Ammerman, A. (2017). Food Policy Council selfassessment tool: D evelopment, testing, and results. Preventing Chronic D isease, 14, 160281. https:// doi.org/ 10.5888/pcd14.160281

Capwell, E. M., Butterfoss, F., \& Francisco, V. T. (2000). Why Evaluate? H ealth Promotion Practiœ, 1(1), 15-20. https:// doi.org/ 10.1177/ 152483990000100103

Caspi, C. E., Sorensen, G., Subramanian, S. V., \& Kawachi, I. (2012). The local food environment and diet: A systematic review. H ealth \& Plaœ, 18(5), 1172-1187. https:/ / doi.org/ 10.1016/ j.healthplace.2012.05.006

Centers for Disease Control and Prevention. (2011). Strategies to Prevent 0 besity and 0 ther C hronic D iseases: The CD C G uide to Strategies to Increase the Consumption of F ruits and V egetables. Atlanta: U.S. D epartment of Health and Human Services.

Chavis, D. M. (2001). The paradoxes and promise of community coalitions. A merican Journal of Community Psychology, 29(2), 309-320. https:/ / doi.org/ 10.1023/ A:1010343100379

Clayton, M. L., Frattaroli, S., Palmer, A., \& Pollack, K. M. (2015). The role of partnerships in U.S. Food Policy Council policy activities. PloS 0 ne, 10(4), e0122870. https:/ / doi.org/ 10.1371/ journal.pone.0122870

DeVellis, R. (2012). Scale development: Theory and applications (3rd ed.). Sage Publications.

Food Policy Network. (2015). Food Policy Council Directory. Retrieved from http:// www.jhsph.edu/ research/ centersand-institutes/johns-hopkins-center-for-a-livable-future/ projects/ FPN/ directory/ online

Freedman, D. A., \& Bess, K. D. (2011). Food systems change and the environment: Local and global connections. A merican Journal of Community Psychology, 47(3-4), 397-409. https:/ doi.org/ 10.1007/ s10464-010-9392-z

Gillespie, G., Hilchey, D ., Hinrichs, C., \& Feenstra, G . (2007). Farmers' markets as keystones in rebuilding local and regional food systems. In C. Hinrichs \& T. Lyson (Eds.), Remaking the N orth A merican food system: Strategies for sustainability (pp. 65-83). Lincoln, NE: University of Nebraska Press

Godfray, H. C. J., Beddington, J. R., Crute, I. R., Haddad, L., Lawrence, D., Muir, J. F., ... Toulmin, C. (2010). Food security: The challenge of feeding 9 billion people. Scienœ, 327(5967), 812-818. https:// doi.org/ 10.1126/ science.1185383

Guenther, P. M., Casavale, K. O., Reedy, J., Kirkpatrick, S. I., Hiza, H. A. B., Kuczynski, K. J., ... Krebs-Smith, S. M. (2013). Update of the Healthy Eating Index: HEI-2010. Journal of the A cademy of N utrition and D ietetics, 113(4), 569580. https:/ / doi.org/ 10.1016/ j.jand.2012.12.016

Harper, A., Shattuck, A., Holt-G iménez, E., Alkon, A., \& Lambrick, F. (2009). Food policy councils: Lessons learned. Institute for $\mathrm{F}$ ood and D evelopment Policy, 1-63.

Hassanein, N. (2003). Practicing food democracy: A pragmatic politics of transformation. Journal of Rural Studies, 19(1), 77-86. https:// doi.org/ 10.1016/ S0743-0167(02)00041-4

Heywood, P., \& Lund-Adams, M. (1991). The Australian food and nutrition system: A basis for policy formulation and analysis. A ustralian Journal of Public H ealth, 15(4), 258-270. https:/ / doi.org/ 10.1111/ j.1753-6405.1991.tb00345.x

Honeycutt, S., Leeman, J., McCarthy, W. J., Bastani, R., Carter-Edwards, L., Clark, H., ... Kegler, M. (2015). Evaluating policy, systems, and environmental change interventions: Lessons learned from CD C's prevention research centers. Preventing Chronic D isease, 12, 150281. https:/ / doi.org/ 10.5888/ pcd12.150281

Hsieh, H.-F., \& Shannon, S. E. (2005). Three approaches to qualitative content analysis. Q ualitative H ealth Research, 15(9), 1277-1288. https:// doi.org/ 10.1177/ 1049732305276687

Hughes, D ., Brown, C., Miller, S., \& McConnell, T. (2008). Evaluating the economic impact of farmers' markets using an opportunity cost framework. Journal of A gricultural and A pplied E conomics, 40(1), 253- 265. https:// doi.org/ 10.1017/ S1074070800028091

Ikerd, J. (2009). C risis and opportunity: Sustainability in A merican agriculture. Lincoln: University of Nebraska Press.

Javdani, S., \& Allen, N. E. (2011). Councils as empowering contexts: Mobilizing the front line to foster systems change in the response to intimate partner violence. A merican Journal of Community Psychology, 48(3-4), 208-221. https:// doi.org/ 10.1007/ s10464-010-9382-1

Jones, P., \& Bhatia, R. (2011). Supporting equitable food systems through food assistance at farmers' markets. A merican journal of public health, 101(5), 781-783. https:/ / doi.org/ 10.2105/ AJPH.2010.300021 
Journal of Agriculture, Food Systems, and Community D evelopment

ISSN: 2152-0801 online

https:/ / www.foodsystemsjournal.org

Leeman, J., Calancie, L., Hartman, M. A., Escoffery, C. T., Herrmann, A. K., Tague, L. E., ... Samuel-Hodge, C. (2015). What strategies are used to build practitioners' capacity to implement community-based interventions and are they effective?: A systematic review. Implementation Scienœ, 10, 80. https:/ / doi.org/ 10.1186/ s13012-015-0272-7

Lyn, R., Aytur, S., D avis, T. A., Eyler, A. A., Evenson, K. R., Chriqui, J. F., ... Brownson, R. C. (2013). Policy, systems, and environmental approaches for obesity prevention: A framework to inform local and state action. Journal of Public H ealth Management and Practioe, 19, S23-S33. https:/ / doi.org/ 10.1097/ PHH.0b013e3182841709

MacRae, R., \& D onahue, K. (2013). M unicipal food policy entrepreneurs: A preliminary analysis of how C anadian cities and regional districts are involved in food system change. Toronto Food Policy Council.

McCartan, J., \& Palermo, C. (2017). The role of a food policy coalition in influencing a local food environment: An Australian case study. Public H ealth N utrition, 20(5), 917-926. https:/ / doi.org/ 10.1017/ S1368980016003001

Mozaffarian, D . (2016). D ietary and policy priorities for cardiovascular disease, diabetes, and obesity. Circulation, 133(2), 187-225. https:/ / doi.org/ 10.1161/ CIRCULATIO NAHA.115.018585

National Academies of Sciences, Engineering, and Medicine. (2017). Communities in action: Pathways to health equity. Washington D.C.: National Academies Press.

Neff, R., Palmer, A., McKenzie, S., \& Lawrence, R. S. (2009). Food Systems and Public Health Disparities. Journal of H unger \& E nvironmental N utrition, 4(3-4), 282-314. https:/ / doi.org/ 10.1080/ 19320240903337041

Nesheim, M., O ria, M., \& Tsai Yih, P. (eds.) (2015). A framework for assessing effects of the food system. Washington, D.C.: The National Academies Press.

O ffice of Disease Prevention and Health Promotion. (2017). Disparities. Retrieved from https:/ / www.healthypeople.gov/ 2020/ about/ foundation-health-measures/ Disparities

Ransom, M., G reiner, A., \& Kochtitzky, C. (2011). Pursuing health equity: Zoning codes and public health. The Journal of L aw, M edicine \& E thics, 39(suppl. 1), 94-97. https:/ / doi.org/ 10.1111/j.1748-720X.2011.00576.x

Roussos, S. T., \& Fawcett, S. B. (2000). A review of collaborative partnerships as a strategy for improving community health. A nnual Review of Public H ealth, 21, 369-402. https:/ / doi.org/ 10.1146/ annurev.publhealth.21.1.369

Ruelas, V., Iverson, E., Kiekel, P., \& Peters, A. (2012). The role of farmers' markets in two low income, urban communities. Journal of Community $\mathrm{H}$ ealth, 37(3), 554-562. https:/ / doi.org/ 10.1007/ s10900-011-9479-y

Sadler, R. (2016). Strengthening the core, improving access: Bringing healthy food downtown via a farmers' market move. A pplied G eography, 67, 119-128. https:/ / doi.org/ 10.1016/ j.apgeog.2015.12.010

Salas-Salvado, J., Bullo, M., Babio, N., Martinez-G onzalez, M. A., Ibarrola-Jurado, N., Basora, J., ... Ros, E. (2011). Reduction in the incidence of Type 2 D iabetes with the mediterranean diet: Results of the PREDIMED-Reus nutrition intervention randomized trial. D iabetes Care, 34(1), 14-19. https:/ / doi.org/ 10.2337/ dc10-1288

Scherb, A., Palmer, A., Frattaroli, S., \& Pollack, K. (2012). Exploring food system policy: A survey of food policy councils in the United States. Journal of A griculture, F ood Systems, and C ommunity D evelopment, 2(4), 3-14. https:/ / doi.org/ 10.5304/ jafscd.2012.024.007

Schiff, R. (2008). The role of food policy councils in developing sustainable food systems. Journal of $H$ unger \& E nvironmental N utrition, 3(2-3), 206-228. https:/ / doi.org/ 10.1080/ 19320240802244017

Sobal, J., Kettel K han, L., \& Bisogni, C. (1998). A conceptual model of the food and nutrition system. Social Science \& M edicine, 47(7), 853-863. https:// doi.org/ 10.1016/ S0277-9536(98)00104-X

Sussman, L., \& Bassarab, K. (2017). Food Policy C ouncil Report 2016. Baltimore, MD: Johns Hopkins Center for a Livable Future. Retrieved from http:// www.foodpolicynetworks.org/ food-policy-resources/ ?resource=933

Thornton, R. L. J., Glover, C. M., Cene, C. W., Glik, D. C., Henderson, J. A., \& Williams, D . R. (2016). Evaluating strategies for reducing health disparities by addressing the social determinants of health. H ealth A ffairs, 35(8), 14161423. https:/ / doi.org/ 10.1377/ hlthaff.2015.1357

Toth, A., Rendall, S., \& Reitsma, F. (2016). Resilient food systems: A qualitative tool for measuring food resilience. U rban E cosystems, 19(1), 19-43. https:/ / doi.org/ 10.1007/ s11252-015-0489-x

U.S. D epartment of Health and Human Services and U.S. D epartment of Agriculture. (2015). D ietary G uidelines for A mericans 2015-2020. 8th E dition. Retrieved from https:/ / health.gov/ dietaryguidelines/2015/ 
Journal of Agriculture, Food Systems, and Community D evelopment ISSN : 2152-0801 online https:/ / www.foodsystemsjournal.org

Vennix, J. A. M. (1996). G roup model building: F acilitating team learning using system dynamics. West Sussex, England: John Wiley \& Sons.

Walsh, C. C., Taggart, M., Freedman, D . A., Trapl, E. S., \& Borawski, E. A. (2015). The Cleveland-Cuyahoga County Food Policy Coalition: "We have evolved." Preventing Chronic D isease, 12, 140538.

https:// doi.org/ 10.5888/ pcd12.140538 